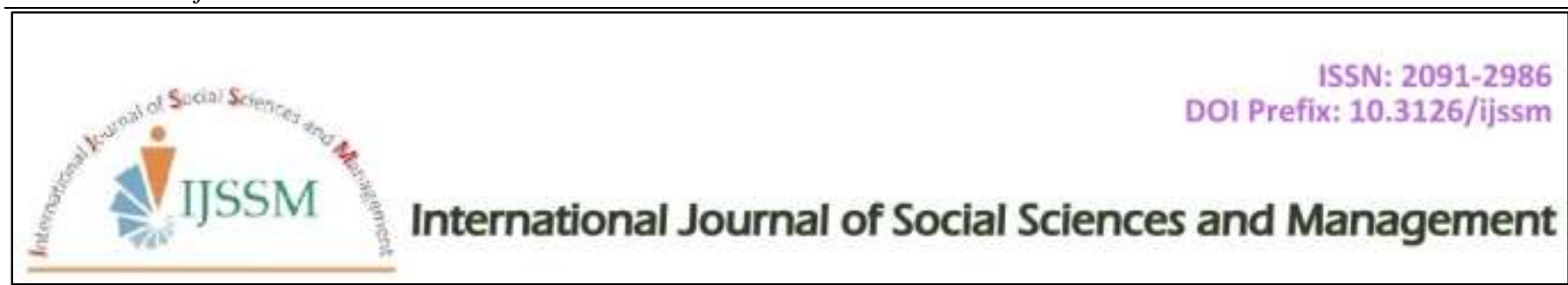

Research Article

\title{
Factors Affecting Academic Performance of Undergraduate Nursing Students
}

\author{
Shaheen Fajar $^{1 *}$, M. Hussain ${ }^{1}$, Hajra Sarwar ${ }^{1}$, M. Afzal ${ }^{1}$, Syed Amir Gilani ${ }^{2}$ \\ ${ }^{* 1}$ Lahore School of Nursing, The university of Lahore, Pakistan \\ ${ }^{2}$ Departments of Allied Health Sciences, The University of Lahore, Pakistan
}

\begin{abstract}
Background: The performance of student play important role to quality education which produce quality graduates . So they took part in development of the country and become leader of that county, They are the backbone of their country(Feenberg, 2012). Most of the students do not make themselves attentive in subject duo to same reason like, school related issues, unconfident and unskilled teachers, insufficient services, and non-availability of instructional materials. Non-school issues involve poverty, low instructive fulfillment and lack of education of guardians and weakness and nutrition (Farooq, Chaudhry, Shafiq, \& Berhanu, 2011).

Objective: To determine the factors that affects the academic performance of students of Lahore school of Nursing, The University of Lahore, Pakistan.

Methodology: A descriptive Cross-sectional Study Students of Lahore School of Nursing, the University of Lahore. Convenient sampling Technique was use for data collection. Participants who are enrolled in BSN (Generic and Post RN), Age was 18 years to 45years, Both Male and Female, married and unmarried students was including. except BSN (Post-RN) and BSN (Generic) was exclude for data collection

Result: Gender of the participant has negative association with Education of participant as sig value is .000 and -.397 . Gender of the participant has association with Marital status and has weak correlation as sig is .159 and $\mathrm{r}$ value is .123. Gender of the participant has association with student related factor and has negative correlation as sig is .397 and $\mathrm{r}$ value is -.074.

Conclusion: In this study conclude that, most of the common contribution factors that affect academic performance of nursing students were related to teacher factor, student factor, home factor, school factors, significantly affect the academic performance of the nursing students.
\end{abstract}

Keywords: Academic performance; Nursing student; undergraduate

\section{Cite this article as:}

S. Fajar et al. (2019) Int. J. Soc. Sc. Manage. Vol. 6, Issue-1: 7-16. DOI: 10.3126/ijssm.v6i1.22563

\section{$1 *$ Corresponding author}

Shaheen Fajar,

Lahore School of Nursing, The university of Lahore, Pakistan

Email: shaheenanwar756@gmail.com

Peer reviewed under authority of IJSSM

(C) 2019 International Journal of Social Sciences and Management

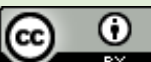

This is an open access article \& it is licensed under a Creative Commons Attribution 4.0 International License (https://creativecommons.org/licenses/by/4.0/)

Full text of this paper can be downloaded online at www.ijssm.org/ \&http://nepjol.info/index.php/IJSSM/issue/archive 


\section{Introduction}

Without students, learning institutes have no value. Learners are main source of any educational set up. These days speedy change in education is a valuable strive of human being. It play an important role to enhance human wealth and also help in personality building and performance that develop Living standard of human being (Feenberg, 2012).

The performance of student plays important role to quality education which produce quality graduates. So they took part in development of the country and become leader of that county, They are the backbone of their country (Grealish, 2012).

Right now, the Understudy as who don't have involvement of English Dialect may not work effectively, in English as a subject as well as in all their scholastic endeavors loves, the effect of English as a medium of correspondence has on the different subjects of the instructive modules interminably demonstrate the way that understudies' execution in the English Dialect impacts their general execution in different subjects (Amua-Sekyi \& Nti, 2015).

Most of the students do not make themselves attentive in subject duo to same reason like, school related issues, unconfident and unskilled teachers, insufficient services, and non-availability of instructional materials. Non-school issues involve poverty, low instructive fulfillment and lack of education of guardians and weakness and nutrition (Farooq et al., 2011).

In this study which enhance their academic learning the factors are affect the quality of cadmic performance of the student like, academic burden creates on parents, peer pressure and psychological factors these are the factors may be modify. Other factors include are physical fitness, age , sex ,technology, stress and sleeping hours but these factor are don't modify (Gupta \& Singh, 2017).

In this study observed that test and academic competence were significantly associated with students' academic performance. Experiential year students' performed better in time management skill, test anxiety, test competence, and academic competence in their second year curriculum (Hijazi \& Naqvi, 2006).

In Udoh study, internal elements are mostly related to student like unqualified teacher, quizzes, assignment, absent from the class and not attend the lectures properly. These eternal elements are controlled while external components because of outside condition like, socioeconomic status, parents' education, peer pressure of students they are uncontrolled. The past incorporate individual circumstances and study propensities while the later incorporate home related issues, school related and educator related issue (Udoh, 2011).
In the other study showed that School-related elements are found outright and ineffective qualified instructors, deficient offices and Lack of instructional resources. Nonschool issues incorporate neediness, low instructive achievement, and absence of education of the guardians, weakness eating routine (Alos et al., 2015).

According to Kimani and Kara, explore the teachers related factor in which delivery of individualized attention to the weak students, regularity of teachers assessment of the students, when teachers complete the syllabus, teachers setting performance goals, teachers professional qualification, and the teachers performance of teaching were important effect on the academic accomplishment (Kimani et al., 2013).

In another research learners' execution, Socio financial factors like support in the class, family pay, and instructor learner proportion, presence of qualified educators in school, mother's and father's training, separation of school and students likewise good impact on the students' routine (Zotorvie, 2017).

Suleman and his fellows study conducted which that educated parent's students have higher academic achievements than the students whose parents are less educated or the un-educated. But some students are don't achieved their goal (Suleman et al., 2012).

Mushtaq and his fellows (2012) study conclude that in which the learner cadmic performance significant affect the Factors communication skills, learning facilities, and proper guidance (Mushtaq et al., 2010).

A study revealed that different school in which learner studies affect the education performance and scholarly achievement of the Lerner. This compressed the perspectives of numerous specialists and educationist in their examination on the impact of secondary school went to on college execution (Birch \& Miller, 2007).

\section{Problems Statement}

Today it is generally reported that students' educational performance is not good, there are many factors which may affect the educational performance of the Learners. Some of them are Teacher related, School related, and Home related factors. According to study results show that three level of the factors that affect the academic performance of the Learners. Teacher related factors very high impact of educational performance of the nursing Learners. Students and School related factor highly impact of educational performance of the nursing students. Home related factors low impact of acade mic performance of the nursing students, but these are the factors affect the academic performance of the nursing students (Alos et al., 2015).

In this study results revealed that most significant factor those affecting academic performance are personal attitude $78 \%$, Teacher personality $50 \%$, Understanding regarding 
subject $89 \%$. Availability of resources (library, internet) $78 \%$ affect the educational performance of the Learners. Family factors affects $5 \%$ to the educational performance of the nursing students (Sharma et al., 2017).

There are following factors which affect the performance of the student's e.g. student's do not actively listen teachers, and do not participate in the class discussion as a result they do not achieve good grades. Students do not prepare assignments timely and frequently absent from class. Students do not use the learning facilities provide by the university like (library, computer lab), and university do not adhere speak English policy.

\section{Research Question}

This research work specifically required to answer this question:

What are the factors that affecting the educational performance of undergraduate nursing students?

\section{Purpose of Study}

To determine the factors, influence academic performance of undergraduate Nursing students.

\section{Variables}

Lists of factors are to be considered to distinguish the influencing issues towards the educational accomplishment of students. Following factors can be involving in student academic performance like Age, Sex, Year level, marital status, Socio-economic status.

\section{Dependent Variable:}

Students, academic performance.

Independent Variable:

Students issue, Home issue, School issue and Teacher issue

\section{Significance of Study}

- This study result was helping the organization to improve the performance of the students. The organization, policy maker for minimize the factors that affecting the performance of nursing students. After this study the organization was conduct the seminar and workshops to improve the teaching strategies that improve the academic performances of the students.

- After this study student was improve the quality of education and learning. The CGPA of the students might be improved.

- With this present study's finding empower the parents to understand and help their children in regards to their school problems and encourage them.

- Significance of Study this researcher may profit the students by enabling them to understand the factor that can influence their academic performance of the students.

- For the educators this investigation may enable them to perceive issues to run over by the students that might be posing an impact in their performance.

\section{Objective}

General objective:

To determine the factors that affects the academic performance of students of Lahore school of Nursing, The University of Lahore, Pakistan.

\section{Hypothesis}

Null Hypothesis:

These are the factors may affect the academic performance of the Nursing students.

\section{Alternative Hypothesis:}

These are the factors may not affect the academic performance of the Nursing students.

\section{Theoretical Framework:}

The intention is to assess these factors affect the decision processes of efforts with the academic preferences of nursing students. This study was assessing four factors that have been identified in the literature review: student related issues, teacher related issues, home related issues, and school related issues (Fig. 1).

\begin{tabular}{|l|}
\hline Student related factors \\
\hline Student related factors \\
\hline Home related factors \\
\hline \hline Teacher related factors \\
\hline
\end{tabular}

Independent variables
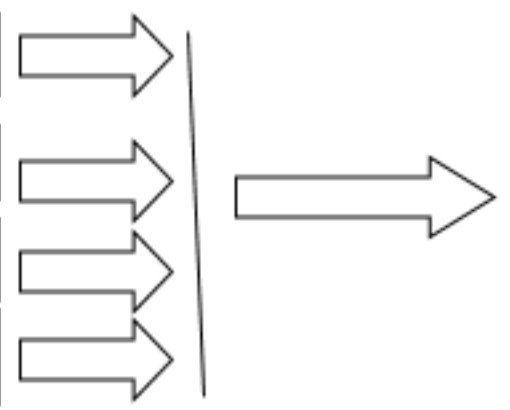

Academic performance

\section{Dependent variable}

Fig. 1: Correlates of Effective Schools (Adapted from Mwaura, 2011) 


\section{Literature Review}

Alshammari, study proved that the instructor related components had a most as to undying Impressive Mean estimation of 4.16 followed by Items of the student-factors issues and school- factors elements and with an equivalent Mean 3.85, while thing home elements, had the least mean estimation of 3.54 (Alshammari et al., 2017).

According to Udoh study showed that our schools mostly have no light, deficient facilities, revolting buildings and no exposure to air. Under these situations the health of learners and teachers may be unpleasantly affected which will cause unpleasant effect on students' performance. To make the students to carry her/his learning successfully and proficiently it is compulsory that learning should be done in favorable environment. (Udoh, 2011)

According to auther study results show that thes are the fectors students affect the low acdamic achivement of the student . $79.3 \%$ factor relate to the learner themselves, absentes from class, old age lerner,mental illness, lack of accdamic motivation in learning, personality dis -order. $15.5 \%$ In this study Gupta \& Singh (2017) rustles show that the $92.3 \%$ students using smart phone, $90.1 \%$ students are using computer and laptops, $97.8 \%$ students are had assess internet and 12, 6\% use personal internet ,77.5\% of the students before examination consuming meals. These are the factors are affect the educational performance of the learners (Gupta \& Singh, 2017).

factors are uneversty envernoment,extera cariculam avtivetise. Family attituedof the student $5.2 \%$ facter relate toward overprotection and overcontrole (Pinyopornpanish et al., 2004).

Therefore, it is appropriate to censoriously look at the ecofriendly factors that effects academic performance of the students. Measures which can help to improve them and to make some commendation because our main educational mission is of enlightening academic performance. (Udoh, 2011)

In this study results Mother and Father Education is positively related to the learners' educational performance. Because the educated parents provide better learning environment at home and facilities to their children, and help their children, motivate the children to improve the study (Raychaudhuri et al., 2010).

According to author highly qualified teachers provide the better education to the students, improved the academic performance of the students and achieved good grades. But untrained teachers do not performed better education to the students as compared to educated teachers (Raychaudhuri et al., 2010).
According to Alos et al advanced education execution is relies on the scholastic achievement of graduate students (Alos et al., 2015; Ali et al., 2013).

Who observed that "the assessment of students and past instructive results are the most extreme imperative pointers of learners future achievement this all studies the higher previous appearance, the better will be the learner's educational impalement in coming days. Complemented to an examination on financial position of the learner's parents and announced that financial status greatly affects the learner's academic order. It demonstrates that significant source of instructive imbalance among the learners and learners academic-performance (Laird, 2005).

They present in this study the influence of social and also monetary detriment in academic presentation of school learners observed, they expressed that the guardians or caretakers who have societal, instructive and money related favorable position completely sustain the level of the accomplishment their child in the future. Be that as it may, Higher Education commission(HEC) recognized challenges that run simultaneously with the present tertiary educational programs of school in the nation (Alos et al., 2015).

Non-school factors incorporate destitution, low instructive achievement, and lack of education of the guardians, weakness and eating routine affect the adcamic performance (Alos et al., 2015; Gatto, 2016; Larson, 2014).

According to Morales at el, a student who is productive in his needed profession has commendable examination propensities. She additionally expressed that learners essential apply these schedules to the greater part of their classes. She additionally prescribed that learners must not attempt to adapting all subjects in single period(Morales, Bang, \& Andre, 2013).

Require investigation alongside insightful what guardians already do with their kids and also how they are good anticipated that would answer totally endeavors to immerse them promote in their kids' learning (Goodall \& Montgomery, 2014).

Guardians' support has been unequivocal and honorable from multiple points of view, Activities that guardians charm in at home and at school and dynamic states of mind guardians have towards training. Rogel and Numerous different examinations reported that expanded recurrence of occasions were related with larger amounts of kid misbehavior in classroom (Rogel, 2012).

This extra ordinarily underlined the significance of having qualified instructors in the field of educating and said that achievement of any program is familiarized by capacity of the educator to educate. On the off chance that there is catastrophe now the whole structure comes up short. Subsequently the business, gathering, arrangement and 
direction of training will have influenced. Furthermore (Glanz, 2000).

Conclude that the good instructors are as often as possible on the mindful for strategies and instructional resources and that will make education important. With the serviceable determination and utilization of assortment of instructional resources or sound, visual resources and encounters might be given to advance students.

\section{Materials and Methods}

\section{Research Design:}

A descriptive Cross-sectional study design was used in carrying out this study.

\section{Research Setting:}

Lahore School of Nursing, the University of Lahore, Pakistan.

\section{Study Population:}

Students of Lahore School of Nursing, the University of Lahore.

\section{Inclusion Criteria:}

Participants who are enrolled in BSN (Generic and Post $\mathrm{RN}$ ) program of Lahore School of Nursing, The University of Lahore was included in this study. The participants Age was 18 years to 45 years, Both Male and Female, married and unmarried students and those who willing to participate was including for study.

\section{Exclusion criteria:}

All students except BSN (Post-RN) and BSN (Generic) age less than 18 years, those who not willing to participate was exclude for data collection.

\section{Sampling Technique:}

Convenient sampling Technique was use for data collection

\section{Sample Size:}

Sample size was calculated by using Slovin'Formula (Slovin, 1960)

$$
\begin{aligned}
\mathrm{n}= & \frac{N}{1+\mathrm{N}(\mathrm{e}) 2} \\
& \text { Total Population }=\mathrm{N}=200
\end{aligned}
$$

Margin of error $=\mathrm{e}=0.05$ at $95 \%$ confidence interval $(\mathrm{CI})$

$$
\begin{aligned}
& \mathrm{n}=\mathrm{N} / 1+\mathrm{N}(\mathrm{e})^{2} \\
& \mathrm{n}=200 / 1+200(0.05)^{2} \\
& \mathrm{n}=200 / 1+200(0.0025) \\
& \mathrm{n}=200 / 1+0.5 \\
& \mathrm{n}=200 / 1.5 \\
& \mathrm{n}=133
\end{aligned}
$$

Sample size was the 133 for this study. (Slovin, 1960)

\section{Instruments and Data Collection}

5 point Likert Scale questionnaire adopted from (Alshammari et al., 2017) was used as a research tool. This inquiry form contains two parts. Part one is about demographic data. Part two is about factors influence academic performance of nursing student. The inquiry for self-possessed of 40 questions characterized as Student associated factors, Home factors, School factors and the Teacher factors. Participant was use the 5 point Likert Scale, composed of 5 to 1 as Always, Often, Sometimes, Rarely and Never.

\section{Ethical Consideration}

Authorized approval was gotten from Ethical Review Committee, Lahore School of Nursing, The University of Lahore. Permission was obtained from participant organization for getting data, and consent form was signed from every participant to take part in study after enlightening the aspect, purpose, and the benefits of research.

\section{Analysis}

Data was analysis by SPSS (statistical package social sciences) version 21 . Outcomes of the study was offered as frequencies, mean, percentage, and the relevant statistical test. Statistical significance was well-thought-out at p-value $<0.05$.

\section{Study Duration}

Study was conducted approximately four months (January, 2018) to (May, 2018).

\section{Results}

Male and female both were participated in this study male was $14.5 \%$ and $83.5 \%$ was female. Participant of different age group participate in this study Participant of age 18-24 years were $31.6 \%, 25-31$ years were $37.6 \%$, 32-38 years were $25.6 \%$ and $39-45$ years were 5.3. Education of the participant is divided into five groups $13.5 \%$ from post $\mathrm{RN}$ (year1), $31.1 \%$ from Post RN(year2), $33.1 \%$ from Generic(Semester3), $16.5 \%$ from Generic(Semester5) and $10.5 \%$ from Generic (Semester7). 9.8\% participant3.6\% were married and $68.4 \%$ were unmarried (Table 1).

Male and female both were participated in this study male was $14.5 \%$ and $83.5 \%$ was female. Participant of different age group participate in this study Participant of age 18-24 years were $31.6 \%, 25-31$ years were $37.6 \%$, 32-38 years were $25.6 \%$ and $39-45$ years were 5.3. Education of the participant is divided into five groups $13.5 \%$ from post $\mathrm{RN}($ year1), $31.1 \%$ from Post RN(year2), $33.1 \%$ from Generic(Semester3), $16.5 \%$ from Generic(Semester5) and $10.5 \%$ from Generic (Semester7). 9.8\% participant3.6\% were married and $68.4 \%$ were unmarried.

In this study show that demographic data Age, gender, education, marital status of the participant effect the academic performance of the students, gender mean value 
$159.76 \%$, St. Dev10.14, F-test 15.49, significance value is 0.0007 . Age mean value is $131.18 \%$,stander deviation $18.90 \%$ and significance value is 0.0003 , education of participant significance value 0.000 (Table 2).
Data shown in the table 3, students related factors highly affect the academic performance of the students mean value $58.14 \%$, stander deviation is $5.64 \%$, significance value is 0.04 . Age of participant mean value is $48.62 \%$, F-test is 30.34 , significance value 0.000 (Table 3 ).
Table1: Demographic Data

\begin{tabular}{llcc}
\hline Gender of Participant & Male & 19 & 14.5 \\
& Female & 111 & 83.5 \\
age of participant & $18-24$ & & \\
& $25-31$ & 42 & 31.6 \\
& $32-38$ & 50 & 37.6 \\
Education of participant & $39-45$ & 34 & 25.6 \\
& & 7 & 5.3 \\
& post RN(year1) & 40 & 30.1 \\
& Post RN(year2) & 44 & 33.1 \\
Marital status of participant & Generic(Semester3) & 22 & 16.5 \\
& Generic(Semester5) & 14 & 10.5 \\
& Generic (Semester7) & 13 & 9.8 \\
& Married & 42 & 31.6 \\
\hline
\end{tabular}

Table 2: Descriptive Statistics relationship between academic performance and factors.

\begin{tabular}{|c|c|c|c|c|c|c|}
\hline Factor & & $\mathrm{N}$ & Mean & St. Dev & F-test & Sig. \\
\hline \multirow[t]{2}{*}{ Gender } & Male & 21 & 159.76 & 10.14 & \multirow[t]{2}{*}{15.49} & \multirow[t]{2}{*}{0.0007} \\
\hline & Female & 112 & 141.55 & 20.69 & & \\
\hline \multirow[t]{4}{*}{ Age } & $18-2$ & 42 & 153.66 & 21.12 & \multirow[t]{4}{*}{16.196} & \multirow[t]{4}{*}{0.0003} \\
\hline & $25-31$ & 50 & 131.18 & 18.90 & & \\
\hline & $32-38$ & 34 & 148.91 & 11.57 & & \\
\hline & $39-45$ & 7 & 161.85 & 2.67 & & \\
\hline \multirow[t]{5}{*}{ Education of Participants } & post RN(year1) & 40 & 147.25 & 14.99 & \multirow[t]{5}{*}{12.343} & \multirow[t]{5}{*}{0.000} \\
\hline & Post RN(year2) & 44 & 142.25 & 15.61 & & \\
\hline & Generic(Semester3) & 22 & 150.68 & 25.66 & & \\
\hline & Generic(Semester5) & 14 & 117.42 & 16.01 & & \\
\hline & Generic (Semester7) & 13 & 161.61 & 17.30 & & \\
\hline \multirow[t]{2}{*}{ Marital Status of Participant } & Married & 42 & 148.50 & 12.87 & \multirow[t]{2}{*}{2.44} & \multirow[t]{2}{*}{1.20} \\
\hline & Unmarried & 91 & 142.54 & 23.00 & & \\
\hline
\end{tabular}

Table 3: Descriptive Statistics Students related factors affect the academic performance of the students.

\begin{tabular}{|c|c|c|c|c|c|c|}
\hline Factor & & $\mathrm{N}$ & Mean & St. Dev & F-test & Sig. \\
\hline \multirow[t]{2}{*}{ Gender } & Male & 21 & 58.14 & 5.64 & \multirow[t]{2}{*}{4.14} & \multirow[t]{2}{*}{0.04} \\
\hline & Female & 112 & 54.33 & 8.21 & & \\
\hline \multirow[t]{4}{*}{ Age } & $18-24$ & 42 & 58.00 & 7.52 & \multirow[t]{4}{*}{30.34} & \multirow[t]{4}{*}{0.000} \\
\hline & $25-31$ & 50 & 48.62 & 6.30 & & \\
\hline & $32-38$ & 34 & 58.41 & 4.31 & & \\
\hline & $39-45$ & 7 & 64.71 & 2.13 & & \\
\hline \multirow[t]{5}{*}{ Education of Participants } & post RN(year1) & 40 & 57.10 & 6.78 & \multirow[t]{5}{*}{11.73} & \multirow[t]{5}{*}{0.000} \\
\hline & Post RN(year2) & 44 & 54.31 & 6.32 & & \\
\hline & Generic(Semester3) & 22 & 55.81 & 8.57 & & \\
\hline & Generic(Semester5) & 14 & 44.14 & 5.44 & & \\
\hline & Generic (Semester7) & 13 & 60.46 & 7.56764 & & \\
\hline \multirow[t]{2}{*}{ Marital Status of Participant } & Married & 42 & 55.3333 & 5.34957 & \multirow[t]{2}{*}{0.154} & \multirow[t]{2}{*}{0.695} \\
\hline & Unmarried & 91 & 54.7473 & 8.94501 & & \\
\hline
\end{tabular}


In this study school related factors are affect the academic performance of the students over results show that sample size is 133 , mean value $16.8 \%$ stander deviation $2.99 \%$, school related factors score is sometime frequency 27 , percentage is $20.3 \%$, often frequency 81 , percentage $60.9 \%$, always frequency 25 , percentage $18.8 \%$. F-test 10.591, significance $0.0001 \%$ (Table 4 ).

Results shown in Table 5 that Frequencies Home related score is Rarely 5 / 3.5\%, sometime 41/30.8\%, Often 49 $136.8 \%$, Always $38 / 28.6 \%$. Home related factors mean value is $36.00 \%$, stander deviation $6.32 \%$, F- test $2.673 \%$, significance value is 0.005 . these results home relate factors affect the academic performance of the undergraduate nursing students.

Table 6 shows that student's academic performances affect that teacher performance, attitude, teaching style, education level of teachers. These are factor affect the student performance, Frequency and Percent Rarely 6/4.51\%, Sometime 33/24.8\%, Often 54/40.6\%, Always 40/30.1\%, Mean value $36.32 \%$, St.dev $4.42 \%$, F-test 13.11, Significance value of this table is 0.002

Table 4: Descriptive Statistics of School related factors affect the academic of the students.

\begin{tabular}{|c|c|c|c|c|c|c|}
\hline Factor & & $\mathrm{N}$ & Mean & St. Dev & F-test & Sig. \\
\hline \multirow{2}{*}{ Gender } & Male & 21 & 21.61 & 1.24 & \multirow{2}{*}{50.70} & \multirow{2}{*}{0.000} \\
\hline & Female & 112 & 16.8 & 2.99 & & \\
\hline \multirow{4}{*}{ Age } & $18-24$ & 42 & 19.23 & 3.47 & \multirow{4}{*}{10.591} & \multirow{4}{*}{0.0001} \\
\hline & $25-31$ & 50 & 15.84 & 2.25 & & \\
\hline & $32-38$ & 34 & 18.17 & 3.43 & & \\
\hline & $39-45$ & 7 & 18.14 & 1.06 & & \\
\hline \multirow{5}{*}{ Education of Participants } & post RN(year1) & 40 & 17.82 & 3.16 & \multirow{5}{*}{8.805} & \multirow{5}{*}{0.000} \\
\hline & Post RN(year2) & 44 & 17.06 & 2.00 & & \\
\hline & Generic(Semester3) & 22 & 18.90 & 4.06 & & \\
\hline & Generic(Semester5) & 14 & 14.28 & 3.26 & & \\
\hline & Generic (Semester7) & 13 & 20.38 & 2.32 & & \\
\hline \multirow{2}{*}{ Marital Status of Participant } & Married & 42 & 18.19 & 2.79 & \multirow{2}{*}{1.792} & \multirow{2}{*}{1.83} \\
\hline & Unmarried & 91 & 17.37 & 3.46 & & \\
\hline
\end{tabular}

Table 5: Home related factors affects the academic performance of the under graduate students.

\begin{tabular}{|c|c|c|c|c|c|c|}
\hline Factor & & $\mathrm{N}$ & Mean & St. Dev & F-test & Sig. \\
\hline \multirow{2}{*}{ Gender } & Male & 21 & 39.80 & 3.23 & \multirow{2}{*}{10.236} & \multirow{2}{*}{0.002} \\
\hline & Female & 112 & 35.20 & 6.42 & & \\
\hline \multirow{4}{*}{ Age } & $18-24$ & 42 & 37.61 & 6.94 & \multirow{4}{*}{2.90} & \multirow{4}{*}{0.037} \\
\hline & $25-31$ & 50 & 34.12 & 6.32 & & \\
\hline & $32-38$ & 34 & 36.00 & 5.06 & & \\
\hline & $39-45$ & 7 & 38.42 & 3.20 & & \\
\hline \multirow{5}{*}{ Education of Participants } & post RN(year1) & 40 & 36.15 & 4.15 & \multirow{5}{*}{2.673} & \multirow{5}{*}{0.035} \\
\hline & Post RN(year2) & 44 & 36.11 & 6.90 & & \\
\hline & Generic(Semester3) & 22 & 37.54 & 7.67 & & \\
\hline & Generic(Semester5) & 14 & 31.14 & 4.81 & & \\
\hline & Generic (Semester7) & 13 & 37.0 & 6.52 & & \\
\hline \multirow{2}{*}{ Marital Status of Participant } & Married & 42 & 38.16 & 6.51 & \multirow{2}{*}{8.25} & \multirow{2}{*}{0.005} \\
\hline & Unmarried & 91 & 34.90 & 5.89 & & \\
\hline
\end{tabular}

Table 6: Teachers related factors affect the academic performance of the undergraduate students.

\begin{tabular}{|c|c|c|c|c|c|c|}
\hline Factor & & $\mathrm{N}$ & Mean & St. Dev & F-test & Sig. \\
\hline \multirow{2}{*}{ Gender } & Male & 21 & 40.19 & 6.19 & \multirow{2}{*}{9.768} & \multirow{2}{*}{0.002} \\
\hline & Female & 112 & 35.13 & 6.90 & & \\
\hline \multirow{4}{*}{ Age } & $18-24$ & 42 & 38.8 & 7.66 & \multirow{4}{*}{8.342} & \multirow{4}{*}{0.0001} \\
\hline & $25-31$ & 50 & 32.6 & 6.99 & & \\
\hline & $32-38$ & 34 & 36.32 & 4.42 & & \\
\hline & $39-45$ & 7 & 40.57 & .53 & & \\
\hline \multirow{5}{*}{ Education of Participants } & post RN(year1) & 40 & 36.17 & 5.61 & \multirow{5}{*}{13.11} & \multirow{5}{*}{0.000} \\
\hline & Post RN(year2) & 44 & 34.75 & 6.16 & & \\
\hline & Generic(Semester3) & 22 & 38.40 & 7.92 & & \\
\hline & Generic(Semester5) & 14 & 27.85 & 2.62 & & \\
\hline & Generic (Semester7) & 13 & 43.69 & 5.42 & & \\
\hline \multirow{2}{*}{ Marital Status of Participantdd } & Married & 42 & 36.80 & 4.01 & \multirow{2}{*}{0.956} & \multirow{2}{*}{0.333} \\
\hline & Unmarried & 91 & 35.52 & 8.03 & & \\
\hline
\end{tabular}




\section{Discussion}

A number of limitations must be acknowledged. First, the study only focused on nursing students, which makes it difficult to generalize the results to all nursing students across the 3 years of the nursing programmers. There are many other factors that could also affect students' academic performance besides age, ethnicity and paid employment. Whilst the link between age, ethnicity and academic performance. The majority of students who worked were employed in a nursing-related position. The world of nursing and healthcare is changing. The impact of these changes together with an acute nursing shortage puts pressure on nursing education programs to teach a larger number of students a greater amount of information in an efficient manner.$^{31}$

The research showed that the academic performance of students of Omer Al Mukhtar University College of nursing correlated positively with their clinical performance. Yoho study with different medical sciences showed a similar correlation between academic performance and clinical performance of students. ${ }^{32}$

In $2004,79.3 \%$ factor relate to the learner themselves, absentes from class, old age lerner,mental illness, lack of accdamic motivation in learning, personality dis -order. As compare to our study $49.6 \%$ respondents said that they use learning facilities. $15.5 \%$ factors related to extera ccurricular avtivetise but in our study $58.6 \%$ factor related to extra curricular activities.

Family attituedof the student $5.2 \%$ facter relate toward overprotection and overcontrole but in our study $48.9 \%$ family like elders guidence to our education.and also a good financial support from family (Mwaura, 2011).

In 2017, factors are affect the academic performance of the students. $92.3 \%$ students using smart phone, $90.1 \%$ students are using computer and laptops, $97.8 \%$ students are had assess internet and 12,6\% use personal internet, $77.5 \%$ of the students before examination consuming meals. In our study $32.3 \%$ use learning material in the library like dictionary, books, and 9\% students library internet use, computers blackboard in class room etc (Glanz, 2000).

Mother and Father Education is positively related to the academic performance of the students. Because the educated parents provide better learning environment at home and facilities to their children, and help their children, motivate the children to improve the study. But in our study $46.6 \%$ parents also help in homework and $45.8 \%$ parents provide specific place provide to the children to study easily at home.

In 2010 Raychaudhuri, et al., highly qualified teachers provide the better education to the students, improved the academic performance of the students and achieved good grades. But untrained teachers do not performed better education to the students as compared to educated teachers. But in our study $53.5 \%$ teachers have a good relationship with students .they help out in studies in proper way (Raychaudhuri et al., 2010).

Sharma et al, revealed that most significant factor those affecting academic performance are personal attitude $78 \%$, $50 \%$ Teacher personality, $89 \%$. Availability of resources (library, internet) $78 \%$ affect the academic performance of the students. Family factors affects $5 \%$ to the academic performance of the nursing students But in our study $89 \%$ school related factor have good academic performance and significant associated with age gender and education of participants.65.4\% home related factor have good academic performance and significantly associated with gender age and education of participants.70.7\% teacher related factor and $81 \%$ school related factor have good academic performance and also significantly associated education of participants and insignificant with marital status (Sharma et al., 2017).

\section{Conclusion}

In this study concluded that these are the factors significantly affect the academic performance of the nursing students .these factors are internal and external ,Students do not listen your teachers curriculum do not mach in the study ,socio economic factor, Student do not used the library internet services provide in school and universities. Parents do not motivate their children's and not provide learning facilities at home Teacher they impose proper discipline are not lenient I strict rules. These are the factors affect the academic performance of the nursing students.

\section{Acknowledgement}

The first author (Shaheen Fajar) is thankful to $\mathrm{Mr}$. Muhammad Sabir for his assistance and guidance for this study. She also expresses gratitude to my honorable teacher Ms. Kousar Parveen her assistance and time to time help and encouragement during this study. The University of Lahore for enlightening us in various aspects and providing us great guide to carry out this research, so. She is also thankful to all the faculty members of Lahore School of nursing, New campus, the University of Lahore.

\section{Limitations of The Study}

Limitations of the study were following

- Sample size $n=133$, which is low and cannot be generalized to the larger population

- There was very short time to conduct this study, which can leads to some scientific and methodological mistakes

- Students were busy in their routine work due to which they don't give enough time to understand and then answer the questions. 
- Data was collected from only students of Lahore School of nursing, The University of Lahore.

- The study used non-probability sampling (convenient sampling method) hence the results could be bias and may not be generalized.

\section{Recommendations}

- Counselling should be provided to students having problems with lack of interest or issues with time management.

- $\quad$ Special language classes can be held for students having difficulty with English.

- Feedback should be given to students with appreciation for good performance.

- Teaching methods should be more interactive \& clinically oriented. Use of both black-board and power point should be encouraged in didactic lectures.

\section{References}

Ali S, Haider Z, Munir F, Khan H \& Ahmed A (2013) Factors contributing to the students academic performance: A case study of Islamia University Sub-Campus. American journal of educational research 1(8): 283-289.

Alos SB, Caranto LC \& David JJT (2015) Factors affecting the academic performance of the student nurses of BSU. International Journal of Nursing Science 5(2): 60-65.

Alshammari F, Saguban R, Pasay-an E, Altheban A \& AlShammari L (2017) Factors affecting the academic performance of student nurses: A cross-sectional study. Journal of Nursing Education and Practice 8(1): 60.

Amua-Sekyi ET \& Nti SK (2015) Factors Affecting Students' Performance in English At Colleges of Education in Ghana. International Journal of Research in Humanities, Arts and Literature 3(10): 29-44.

Birch ER \& Miller PW (2007) The influence of type of high school attended on university performance. Australian Economic Papers 46(1): 1-17.

Farooq MS, Chaudhry AH, Shafiq M \& Berhanu G (2011) Factors affecting students' quality of academic performance: a case of secondary school level. Journal of quality and technology management 7(2): 1-14.

Feenberg A (2012) Questioning technology: Routledge.

Gatto JT (2016) Both Sides Now of a Learning Revolution. "I Love Learning; I Hate School": An Anthropology of College, 237.

Glanz J (2000) Supervision: Don't Discount the. Paradigm debates in curriculum and supervision: Modern and postmodern perspectives, 70 .

Goodall J \& Montgomery C (2014) Parental involvement to parental engagement: a continuum. Educational Review 66(4): 399-410.
Grealish L (2012) How competency standards became the preferred national technology for classifying nursing performance in Australia. Australian Journal of Advanced Nursing 30(2): 20.

Gupta A \& Singh AK (2017) A study to assess factors affecting the performance of undergraduate medical students in academic examination in community medicine. International Journal of Community Medicine and Public Health 4(4): 1066-1070.

Hijazi ST \& Naqvi S (2006) Factors affecting Students' performance. Bangladesh e-journal of Sociology 3(1).

Kimani GN, Kara AM \& Njagi LW (2013) Teacher factors influencing students' academic achievement in secondary schools in Nyandarua County, Kenya. International journal of education and research 1(3): 1-14.

Laird TFN (2005) College students' experiences with diversity and their effects on academic self-confidence, social agency, and disposition toward critical thinking. Research in higher education 46(4): 365-387.

Larson J (2014) Radical equality in education: Starting over in US schooling: Routledge

Morales TM, Bang E \& Andre T (2013) A one-year case study: Understanding the rich potential of project-based learning in a virtual reality class for high school students. Journal of Science Education and Technology 22(5): 791-806.

Mushtaq M, Majrooh M, Ahmad W, Rizwan M, Luqman M, Aslam M and Shad M (2010) Knowledge, attitudes and practices regarding tuberculosis in two districts of Punjab, Pakistan. The international journal of tuberculosis and lung disease, 14(3): 303-310.

Mwaura JM (2011) Strategies employed by secondary school principals to improve academic performance in Embu District.

Pinyopornpanish M, Sribanditmongkok P, Boonyanaruthee V, Chan-ob T, Maneetorn N \& Uuphanthasath R (2004) Factors affecting low academic achievement of medical students in the faculty of medicine, Chiang Mai University. Chiang Mai Medical Journal 43(1): 15-23.

Raychaudhuri A, Debnath M, Sen S \& Majumder BG (2010) Factors affecting students' academic performance: A case study in Agartala municipal council area. Bangladesh ejournal of Sociology 7(2): 34-41.

Rogel RI (2012) Academic behavior and performance of third year students of general Emilio Aguinaldo national high school, division of cavite.

Sharma P, Singh P, Kalhan S and Garg S (2017) Analysis of Factors Affecting Academic Performance of MBBS Students in Pathology. Ann. Int. Med. Den. Res. 3(5): 915.

Slovin E (1960) Slovin's formula for sampling technique. Retrieved on February, 13, 2013.

Suleman Q, Aslam HD, Hussain I \& Shakir M (2012) Effects of Parental Socioeconomic Status on the Academic Achievement of Secondary School Students in District 
Karak (Pakistan). International Journal of Human Resource Studies 2(4): 14.

Udoh NA (2011) Remote Causes and Counseling Implications of Examination Malpractice in Nigeria. Inquiries Journal 3(10).
Waddill-Goad S (2016) Nurse Burnout: Overcoming Stress in Nursing: Sigma Theta Tau.

Zotorvie JST (2017) Students' Accommodation and Academic Performance: The Case of Ho Technical University, Ghana. European Scientific Journal 13(13). 